Eeva Aarnio and Kyösti Pekonen

\title{
CHANGING CONCEPTIONS OF PARTY PROGRAMMES IN FINLAND
}

From the Ideas of 'Government by the Best' and 'Manifesto Democracy' towards the Idea of a Party Programme as an Initiator of Debate

\section{Introduction}

$T_{\text {party programmes in Finland from the early 1950s to the 1990s. }}^{\text {he aim }}{ }^{1}$ One problem of the research on political parties has been that discussion and research on the role of party programmes is too often missing. ${ }^{2}$ At best you will, in general, find only more or less loose remarks about the role and conceptions of party programmes. The main pitfall of the discussion of party programmes has been that programmes have usually been studied from one-side only, i.e., concerning their plans and promises for future action. However, party programmes also have other roles and functions which too often have been neglected by researchers. ${ }^{3}$

In this study of the conceptual changes in the party programmes we want both to revise the contemporary discussion on the changes 
in party politics and to make a contribution to a better understanding of changes in the Finnish political culture. Our findings, on the one hand, confirm the general trend towards the model of a cartel party and, on the other hand, indicate the specific Finnish schedule for the changes. Changing conceptions also show, in an illuminating way, that traditions of political representation are today mixed in such a way that parties no longer have a self-evident understanding of what their representative role in fact means. Our main argument is that, because of the increasing political contingency, it is increasingly more difficult to write a party programme in a traditional sense: that is, to define and to determine in advance what the principal goals of a party in the coming years will be, when international and national surroundings are in turbulence, how to carry out the programme in a situation which is changing all the time, and whom the party is representing when voters are becoming more volatile all the time.

\section{Approaches to the Party Programmes}

Our main interests in the article are: first, to adapt a conceptual analysis to the analysis of party programmes, then to analyse changing conceptions of party programmes with respect to the ideas of political representation, and the stages of party development. By using these three approaches we try to combine the following three aspects: the development of organising political representation, the changing models of party development, and the rhetorical viewpoint in politics. All three aspects are important in understanding the changing conceptions of party programmes.

\section{(a) The Analysis of Concepts}

As in other northern European countries, political parties in Finland also have a strong tradition of programme writing. Since the first elections of the unicameral parliament with universal suffrage in 1906, all the parties offered explicit programmes. ${ }^{4}$ According to the 
"Party Law" from 1969, the programme is a precondition for getting a party officially registered.

In spite of this long history of party programmes in Finland, research of party programmes was a popular topic as late as the 1960s when manifestos were studied as 'papers' telling about the identities, characteristics and policies of parties. Political scientists were inspired by the methods of content analysis, for instance. In general, the focus was on current ideological questions in manifestos. These were, then, contrasted with debates on the 'end of ideologies', to left-right dimensions, or to the historical background of parties. At the end of the 1980s, research on party programmes revived again in accordance with the linguistic turn in political science. It became common to see a programme as action in itself, a specific genre for interpreting current political culture. At present, political science research on party programmes focuses often on the linguistic aspects of texts (i.e., argumentation, rhetoric, and concepts). Thus, new dimensions of programmes, including acts, symbols, political language and communication have gained significant relevance (Aarnio 1998, 21-23).

An important approach for studying the legitimation of conceptual changes has been presented by Quentin Skinner. Conceptions that political actors and people have about a party programme can be seen as a way of thinking, which both set rules for feasible action and also make the action feasible. This is the way Quentin Skinner describes the role of concepts in thinking. Let us take an example about principles. Skinner (1974a and 1974b) explains the role of principles in politics, focusing on intentions in speech acts and possibilities to manipulate the existing speech act potential of a vocabulary. Skinner sees the principles as playing the role of legitimisation in choices which every actor has to do. Principles are constitutive for policy choices, for instance. The available range of action to an actor is limited by the chances to justify the action and justification, again, is dependent on recognisable political principles.

Skinner speaks about the ideal type of innovating ideologist who is obliged to legitimate a new range of action in terms of the existing ways of applying the moral vocabulary prevailing in his/her society. On one hand, an innovative ideologist has to refer to some already accepted political principles as a means of seeking to legitimate his or her own - maybe disapproved or unfavourable - actions. On the 
other hand, an innovating ideologist can reach reinterpretations of policies or revisions of principles with conceptual changes which legitimate those unfavourable actions (1974b, 296-298). In other words, when an agent identifies the principles to manifest this also puts bounds to policies available, which are by no means fixed, but can be reinterpreted and legitimated with conceptual changes.

The general conclusion of the case of an innovative ideologist derives from the fact that any course of action is inhibited from occurring if it cannot be legitimated. This means that any principle, which helps to legitimate a course of action must be among the enabling conditions of its occurrence. The more specific conclusion derives from the fact that the nature and range of the evaluative concepts which any agent can hope to apply in order to legitimate behaviour can in no case be set by the agent himself or herself (1974b, 299300).

In brief, if we apply this to party programmes we can draw from Skinner's discussion the conclusion that programmes are important even if their writers or others deny that. The meanings or interpretations are not limited to those the writers identify, but all political agents can utilise programmes for their own purposes. Purposes are, however, circumscribed both by principles agreed in party programmes and also conceptions of party programmes. Therefore, thinking, reflecting and speaking about principles in a party programme process are important for future action and that is why a programme process with its many phases is always important.

However, it is not self-evident what expectations people have about a party programme in different situations. Eeva Aarnio has analysed (Aarnio 1998) both the concept of the manifesto in the party arena and the conceptual changes that took place during the period of 1950 tol990 in Finnish parties. The concept of a party programme cannot be defined unambiguously because there is no one definition which would cover every situation and every party and on which every political actor could agree. It is, however, possible to study the use of concepts, i.e., conceptions of party programmes. This means necessarily that there can simultaneously exist variable conceptual assumptions and interpretations of the concept of a manifesto. Aarnio's analysis focused on the development of the concept by trying to indicate the main changes of conceptions in party programmes. 
Her conceptual analysis also indicated that subsequent interpretations do not succeed in displacing earlier ones. Various interpretations of the concept of a manifesto are accumulated, as well as a range of expectations concerning its status and use. Many conceptions of a party programme can, on one hand, be understood to signify the plurality of the concept of a political party: that there no more exists one ideal model of a party. There are only different kinds of political parties with different ideas about what a political party is. On the other hand, many conceptions can be understood to represent 'a critical era' in which traditional ideas of the role of political parties in a democratic process and in organising political representation become challenged.

\section{(b) Stages of Party Development}

Conceptions of party programmes do not change at random or in a vacuum. Different conceptions mean different questions and different answers to the questions. Stages of party development can also be seen as new questions which demand new answers.

Richard S. Katz and Peter Mair (1995) present, in their well-known article, the following stages of party development. First, parties were usually of the "cadre" type. Then the socialist parties in particular gave rise to the "mass-party" model. The beginnings of an erosion of traditional social boundaries in the late 1950s and 1960s led to the emergence of what Otto Kirchheimer (1966) called the 'catch-all party'. The latest stage is, according to Katz and Mair, the development of the "cartel party" model.

According to Katz and Mair $(1995,17)$, the emergence of cartel parties is uneven, being more evident in those countries in which state aid and support for parties is most pronounced, and in which the opportunities for party patronage and control are most enhanced. Katz and Mair claim that "the process is likely to be most developed in countries such as Austria, Denmark, Germany, Finland, Norway and Sweden, where a tradition of inter-party cooperation combines with a contemporary abundance of state support for parties, and with a favouring of party over patronage appointments, offices and 
so on." We discuss below whether the Finnish case really gives support to Katz's and Mair's hypothesis and what the stages of party development might mean to the conceptions of party programmes.

\section{(c) Traditions of Political Representation}

The stages of party development in Western democracies are connected to the problems of political representation and to the ideas and traditions of representation in general. According to Anthony F. Birch (1993), there have been three main traditions of political representation in Western democracies: 'the people as sovereign', 'parliament as sovereign', and the third tradition is what Birch calls a 'manifesto democracy'.

In the first case, sovereignty is inherent to the people. Political representatives are regarded as deriving their authority from the people. The people should always keep the politicians in check, for example, through frequent elections. This doctrine, of course, has its 'eternal' value in democratic thinking. But when we think about political representation organised through political parties - and the Finnish case in particular - it is evident that the traditions of 'parliamentary democracy' and 'manifesto democracy' are more important here.

According to the doctrine of 'parliamentary democracy', sovereignty belongs to the parliament. The parliament should represent the whole nation and, accordingly, should decide independently what the general interest and the will of nation are concretely in each case. Members of parliament should not be bound by the instructions of their constituents and electors. On the contrary, the elected representative should be viewed as an independent maker of national laws and policies.

The doctrine according to which sovereignty belongs to the parliament is accompanied by the Burkean idea that the best of the nation' should be members of parliament. It would be beneficial to the nation if the 'best' are gathered together in parliament to discuss freely and independently and decide the will of the nation. 
Birch describes the theory of 'manifesto democracy' as follows: "Each party has a duty to present the electorate at a general election with a detailed manifesto setting out the policies that the party proposes to follow, and the legislative changes it proposes to introduce, if it wins the election and forms the next government. The incoming government would then be entitled to claim that it had a mandate from the electors to carry out its promises and would therefore be acting democratically in using party discipline to press these policies through Parliament" (Birch 1993, 64).

It is evident that the different traditions of democracy and political representation give different answers concerning the role of parties in organising democracy and also concerning the idea of a party programme. For example, programmes are in closer association with electoral behaviour and government policies in two-party systems than in multi-party systems. Voters have then, in principle, an opportunity to base their vote on one particular party programme and to expect the winning programme to be carried out. It is also evident that political parties are leaning on different traditions and that the importance of traditions varies in different political cultures and eras. Finally, individual political actors favour different traditions. Ultimately, this is related to the variable conceptions of a party manifesto. We discuss below how traditions have influenced Finnish parties.

\section{Stages of Party Development and Changing Conceptions of Party Programmes in Finland ${ }^{5}$}

According to Aarnio's (1998) analysis, four general historical phases can be discerned in the changing conceptions of party programmes since the 1950s. Party programmes were written without controversy concerning either content or form in the 1950s and the early 1960s. Completed manifestos were thought to stand for the policies parties were to carry out. At the end of the 1960s, however, the concept changed towards a more ideological debate in wider and more public forums than earlier. Younger generations began to challenge older 'conservative' generations and their institutionalised way 
of thinking. The number of programmes also multiplied and diversified radically. In the 1980s, party executives started emphasising the problem of an organisational democracy, especially from the viewpoint of the writing process of a manifesto. It was thought that an increasing participation in preparing a new manifesto for the party would also democratise the party or, at least, its image. However, it was laborious to inspire members to participate in the process. On the other hand, there also occurred a move towards a more innovative and open programmatic process because of the broader possibilities for politicisation due to increasing political contingency. It seems that in the 1990s increasing political contingency has become a new challenge for parties. One indication of this has been that parties are increasingly in a position in which they themselves have to decide what issues they should choose to emphasise in their programme. Choosing means reflecting on the future relevance of different issues, and in this, the party should at least demonstrate that it is up-to-date. The process of creating a party programme is also an essential arena for practising and maintaining politicians' own political thinking. Parties also must listen more sensitively to other political actors, and react more flexibly to their debate initiatives. This means that parties seem to be losing their independent role, which was so strong in Finland from the 1950s to the 1970s in particular. In the 1990s there are clear signs indicating that devising a party programme in the traditional sense, i.e., a 'big ideological narrative' covering several years, has become all the more difficult for parties.

This brief description of the changing conceptions concerning party programmes in Finland indicates that a party programme process, i.e., the whole process of discussing and writing a new programme, the decision-making process of a new programme, and the use of the approved programme, has many other 'functions' than being merely a promise for future policies. But before discussing this in detail we must start from the beginning by showing the layers and tensions between them in the current conceptions of a party programme. Historically the first layer is the idea that the "parliament is sovereign', which is accompanied by the cadre-party model typical to it. 


\section{The Cadre-Party Model}

The idea of 'parliament as sovereign' strives for the 'government by the best' which, again, results in the cadre-party model in the political arena.

Katz and Mair (1995, 9, 19-20) argue that, in the traditional cadreparty model, parties were more or less loose groups of intellectuals and political activists. Parties were basically committees of people who jointly constituted both the state and the civil society. While the elite were 'ordinary' members, there was little need for intermediaries, or in other words for a formal or highly structured organisation. In the period of dominance of the elite party, political goals and conflicts largely revolved around the distribution of privileges, and the parties competed on the basis of the ascribed status of their adherents. Among the elite parties, competition was effectively managed and controlled.

Even if we do not discuss here the history of the cadre-party model in Finland, there are good reasons to argue that parties favouring the tradition of the 'parliament as sovereign', and in which party programmes are seen as more or less tight plans to be carried out, have always been a problem. In the Finnish case, the tradition of the "parliament as sovereign' has been strong among bourgeois parties and in the National Coalition Party in particular.

The Agrarian Party has also leaned on the non-socialist programme tradition: attitudes towards a programme were based on the idea that policies depend on intellectual consideration. A 'theory of society', i.e., the idea of 'scientific politics' and a scientific planning of society, has been unfamiliar to both of these parties. Nationwide/ centralized policy programmes are unfamiliar to the National Coalition Party. The Agrarian Party has been closer to the socialist party programme tradition in this respect. Restricted, predestined doctrine has not, however, been included in their traditions. Instead, both parties have traditionally emphasised general principles, individually labelled goals towards a better society, and the educational aspects of a manifesto. Though systematic references to ideological and theoretical literature have been neglected, they still have had strong 'ideological' leaders. These leaders, especially in the Agrarian/ 
Centre Party, have advanced to become party executives, and thus gained high operational leadership. 'Foundation ideas' have historically been stressed in the Agrarian/Centre Party, but practicality of 'ideology' also has been given a high priority.

The first decades under examination (Aarnio 1998), the 1950s and the early 1960s, can be referred to as periods in which 'harmony' and 'solidarity' were emphasised in the forum of manifestos. Discordant notes were not allowed inside parties. Paradoxically, debates concerning principles - occurring during the writing process were always reported to be vivid. This rhetorical move aimed at increasing the feeling of integrity. The undeniable task of writing a manifesto in nonsocialist parties was to make the principles of a party better known to voters. Thus, the election results and the programme were seen as closely related, but in a different manner than in a 'manifesto democracy'.

The National Coalition Party was the first nonsocialist party that invited rank-and-file members to participate in the writing process of the manifesto, thus following the tradition of a 'mass party' and acting contrary to the doctrine of 'parliamentary democracy'. It was not customary for the rank-and-file members to question the academic elitist way in which programme drafts were usually written. In spite of the opportunity to give feedback, the great majority of party members were excluded from the process until its completion, i.e., when final decisions were made in party congresses. Party members were, however, emphatically encouraged by the party executive to distribute the completed programme. It is evident that both the writing process and renewed manifesto had a strong symbolic impact in seeking and emphasising the unity of the party. Programmes were also used as means for reinforcing the confidence in electoral victory even if programmes were not seen as detailed plans for overcoming social and political problems. Programmes of the bourgeois parties were seen rather as a presentation of basic values adapted to the current society and situation. In that sense programmes had to be up-to-date.

The tradition of the 'parliament as sovereign' is not, however, only past history. On the contrary, we can see this tradition almost daily; debate concerning the free or bound mandate of the MPs is an illuminating example in this respect. 


\section{The "Mass-Party" Model}

Where the traditional cadre party had relied on the quality of its leaders and supporters, the new "mass party" relied on its quantity of supporters. The ability to mobilise became the first criterion when the success and power of a party were assessed.

Organising political representation through a 'manifesto democracy' and the mass-party model are tightly connected. Katz and Mair (1995, 6-7) describe the mass-party model in the following way:

In the archetypal mass-party model, the fundamental units of political life are pre-defined and well-defined social groups, membership in which is bound up in all aspects of the individual's life. Politics is primarily about the competition, conflict and cooperation of these groups, and political parties are the agencies through which these groups, and thus their members, participate in politics, make demands on the state, and ultimately attempt to capture control of the state by placing their own representative in key offices. Each of these groups has an interest, which is articulated in the programme of 'its' party. This programme is not just a bundle of policies, however, but a coherent and logically connected whole. (Katz and Mair 1995, 6-7)

Most important in a 'manifesto democracy', organised through mass parties, is that the voters are supporting one or the other party, and this support is expressed by voting in elections for a well-defined programme. A 'manifesto democracy' presupposes that the competition between parties means competition between programmes. Party programmes should be 'plans and promises for the future', i.e., they should be clear and transparent about what the party is going to do if it wins elections and gets governmental power. Programmes as plans and promises for future action would also allow voters to control their representatives and parties. Elections become choices of delegates rather than trustees, and delegates are more or less tightly bound to the party and fulfilling its programme.

At least after the 'turn to the Left' in the 1966 parliamentary election, the 1960s appeared in Finland to be a time for the hope of rational planning of the whole society and the widely shared belief in constant growth. Consequently, completed manifestos proved to 
be equal to policy; i.e., they provided the instructions and means of achieving given targets. When manifestos were interpreted as answers, as building plans, or, for example, as solutions to the central problems of Finnish society, it was essential that there was a very strong belief in party ideologies. So, as late as the 1960s, memorisation of the texts in manifestos was strongly encouraged. For example, when parliamentary candidates gave speeches, they at least highlighted speeches by repeating ideological slogans and statements derived from the manifestos. The competence of candidates was also reinforced in that way.

At the time of centralized policy programmes, there were no major differences in the understanding of the character of party programmes. The general public was ready to give to parties the leading role in the presentation of 'answers' to political questions. Since this time, however, the consensus concerning the party programmes has disappeared.

A 'manifesto democracy', with its mass-party model, is usually seen as a model and challenge posed by the socialist parties. It was thought that other parties would be obliged to adopt the basic features and strategy of the socialist/mass-party model or they would otherwise perish. This seems also to have been the case in Finland in the late 1960s and at the beginning of the 1970s when conceptions of party programmes in the Conservative Party and in the Centre Party in particular changed radically in that direction. This is one sign of the hegemony of the Left in Finland since the 1966 parliamentary election.

\section{The "Catch-All Party" Model}

A third stage of evolution is the 'catch-all party', in which parties from both the traditional left and right are beginning to converge towards a 'catch-all party' model. The emergence of the 'catch-all party' challenged the notion of the party as representative of predefined sectors of society. One could say that contingency concerning the basis of a party's political arena began to increase. Katz and Mair (1995, 7-8) mention the beginnings of an erasion of traditional 
social boundaries as one of the critical causes of political contingency. They also emphasise the role of the growth of the economy and the increased importance of the welfare state. According to Katz and Mair, these factors facilitated the elaboration of programmes that were no longer necessarily divisive nor partisan, but that could be claimed as serving the interests of all, or almost all. The development of the mass media is also very important because the media allowed party leaders an easy means of appealing to the electorate at large. Also, the electorate had changed. Katz and Mair argue that in the 'catch-all' situation an electorate is made up of voters who are learning to behave more like consumers than active participants. The overall result in respect to elections was: "elections were now seen to revolve around the choice of leaders rather than the choice of policies or programmes, while the formation of those policies or programmes became the prerogative of the party leadership rather than of the party membership". (Katz and Mair 1995, 8)

The 'catch-all party' poses new challenges to traditional concepts of party programmes. Katz and Mair claim $(1995,13)$ that "instead of emphasising social homogeneity, the party accepts members wherever it finds them, and moreover recruits members on the basis of policy agreement rather than social identity." This means putting problems of social and political identity more and more aside in writing programmes and emphasising policy formulations.

In the 'catch-all party' model, parties are brokers between civil society and the state. "On one hand, parties aggregate and present demands from civil society to the state bureaucracy, while on the other they are the agents of that bureaucracy in defending policies to the public" (Katz and Mair 1995, 13). This means also that the capacity of a party to perform the brokerage function depends not only on its ability to appeal to the electorate, but also on its ability to manipulate the state (ibid., 14). This kind of situation in Finland resulted in the explosive increase of special programmes in parties in the 1970s.

In the 1960s and 1970s, the framework of public administration and state budget were followed in writing special programmes. This explains the wide utilisation of civil servants' knowledge in the writing process of manifestos. Special programmes were initially prepared for helping to achieve supreme decision making in parties. 
The 'necessity' of special programmes was motivated by the re-entrance of the Social Democratic Party to government in 1966. They quickly needed information concerning all administrative districts, i.e., all imaginable sectors of policy, such as social policy, agricultural policy, educational policy, as well as fishing policy, cultural policy, or even tourism policy. While party programmes were accepted after a long and hierarchical process, which normally took more than a year, special programmes were sometimes accepted without delay when party executives needed them.

The National Coalition Party and the Centre Party followed the example of the Social Democrats. In all parties working groups of experts were set up to write, revise and confirm special programmes. For example, in the Centre Party altogether 34 Special programmes were created between 1966 and 1979 (Blåfield \& Vuoristo 1981). This trend estranged the rank-and-file members from the writing process of manifestos, resulting in programmes which were totally unknown to party members, and sometimes even the mutual logic of valid programmes limped. This, among other things, led in the 1980s to a situation in which the number of programmes were radically decreased. This emphasised again the value of a party programme, but at the same time it increased their diversity.

Parties and the electorate began to drift apart in Finland in the 1960s. Already in 1959, the Finnish political scientist, Jaakko Nousiainen (1959, 16-17), argued that wide ideological differences between parties had considerably blurred, and the differences had only a restricted effect on their relationships. However, the writing of manifestos was more active than before or ever since. The 1960s has frequently been remembered as a very ideological period. It is true that the status of parties was strengthened and party organisations were active. The question was not, however, about ideological originality but rather about the quantity of programmes. Parties competed more clearly for the same audiences.

The period between 1967-1975 was significant for the status of parties. Parliament passed the first legislative act pertaining to parties in 1969. The act was necessitated by the state subsidies paid to party organisations since 1967. "Party Law" also attempted to prevent the further splitting of parties. It ruled that, after the 1970 election, only registered political parties would be allowed to nominate 
candidates in parliamentary elections. The monopoly granted to registered parties in 1969 met heavy criticism, and in 1975 it again became possible to nominate 'wild' candidates (Pesonen 1995, 14). However, "Party Law" can be seen as an important starting point and prerequisite for the development of the "cartel-party" model in Finland.

\section{The "Cartel-Party" Model and the Problem of Increasing Political Contingency}

Katz's and Mair's main argument $(1995,5)$ is that "the recent period has witnessed the emergence of a new model of party, the cartel party, in which colluding parties become agents of the state and employ the resources of the state (the party state) to ensure their own collective survival. ... Parties have now become semi-state agencies" (ibid., 16). The cartel party is characterised by the interpenetration of party and state, and also by a pattern of interparty collusion. Because all of the main parties can survive together, the conditions become ideal for the formation of a cartel.

The formation of a cartel-party situation also has its effects on elections. According to Katz and Mair (1995, 16), "winning or losing in elections may make less difference to a party's political objectives because of the absence of great policy battles, but could make a good deal of difference to its sheer survival, since the resources for its sustenance now come increasingly from the state."

The pattern of electoral competition in a cartel situation is contained and managed. "Certainly, the parties still compete, but they do so in the knowledge that they share with their competitors a mutual interest in collective organisational survival ... Stability becomes more important than triumph" (ibid., 19-20, 23). All this has its effects on democracy too.

"The essence of democracy lies in the ability of voters to choose from a fixed menu of political parties. Parties are groups of leaders who compete for the opportunity to occupy government offices and to take responsibility at the next election for government performance" (ibid., 21). 
What does the cartel-party model then mean to the idea of a party programme? Katz and Mair argue $(1995,22)$ that party programmes become more and more similar. It really seems that at least the cartel parties do not need a party programme in the traditional sense, i.e., an ideological narrative which gives the party and its supporters a common collective identity and clear tasks which the party strives to carry out if it gets government power.

A cartel situation also has its weaknesses. The cartel-party model aims for stability and a reasonable status quo. Depoliticised contested competition is the spontaneous way of attaining this aim. However, a cartel situation can - for many reasons - be only a transitory solution. A cartel always has enemies both within and outside the cartel. The most dangerous enemy is without a doubt the contingency that is always present in the structure and rules of a cartel situation.

One of the main feature of political parties in Western democracies has been that political parties are the only organisations which operate in the electoral arena and compete for votes (Panebianco $1988,6)$. In principle, from the viewpoint of political parties, winning the elections appears as the central aim of politics. Elections are the paradigmatic action situation with which other politics are related. The party is the organisation which nominates its candidates in elections and which either wins or loses elections. The professional skill of a political leader and a politician means from this point of view an art of winning elections. Therefore, the 'work' of a politician is arranging potential electoral victory (Bryce 1886/1889; see also Palonen 1997).

It has, however, been argued that the main Finnish political parties have for decades been more or less 'reluctant' to win elections at all costs (see, for example, Pekonen 1997). This has been possible for many reasons. One reason has been that Finnish politics has experienced a relatively stable period, with more or less stable political alignments and without critical elections. (On the concepts of critical elections and a stable era, see Aldrich 1999). Candidate-centered elections have marked this stable era in Finland. (For more on the Finnish case, see, for example, Pekonen 1984, 1986, and 1995). It has also been argued that Finnish politics has not 'traditionally' been action-centered politics, but that rather con- 
sensus has been emphasised. This can be seen in the hegemonic position the Finnish foreign-policy paradigm - the so-called Paasikivi - Kekkonen foreign policy and its demand on national consensus in foreign-policy opinions - had in domestic politics since World War II and up until 1991. Other examples are such metaphors as "consensus", the "politics of low profile" and a "rhetoric of necessity" which were widely used in describing Finnish politics in the 1980s. When major political actors have been consensus-oriented, competition in elections has not meant a 'wholehearted' struggle between main parties, but rather a contested competition inside a market situation of an oligopoly. A big problem of contested competition has been the underestimation of voters. Jaakko Nousiainen argued already at the end of the 1950s (1959, 103) that during the power of bureaucratic mass parties it may be that the party system would not accurately reflect the distribution of opinions among voters, but rather that the distribution was a reflection of the party system. However, this situation has slowly been changing in Finland too. The change of parties towards catchall parties, election parties, and cartel parties have been changing the role of parties in the political system, their representative role in particular and, therefore, also the conceptions of party programmes. One overall result of these changes may be the intensification of the electoral struggle between parties.

The background for these changes can be found in the increasing political contingency. Many studies have shown that voter turnout has steadily decreased in Finland, the number of parties has increased, new small parties have steadily claimed an increasing proportion of votes cast, voters' volatility has increased and the citizens' indifference to parties and politicians has been increasing ${ }^{6}$. These and other new challenges have broadened the scope of political action and opened new chances for politicisation. The more things are in 'turmoil', the more the political situation gives a free hand - or at least new chances - for political actors to act. The important point here is that the question is no longer merely of endeavours to get rid of contingency or 'tame' it, but now also chances provided by the increasing political contingency are taken into consideration as realistic categories in reflecting action possibilities (see, for details, Palonen 1997). Freedom of action has grown, but what results from it will be 
depend on the political actors themselves. Political leaders in particular will face new pressures in this respect.

One basic idea of the nationwide/centralized planning was to minimise contingency, by trying to deal beforehand with contingent events, by lessening the chance that they would happen. This kind of 'rational politics' neglected, among other things, the idea of politics as sort of a creative force: as an art to utilize possibilities which exceptional situations, and unexpected and unwanted consequences of action open up for the political actors.

As we already mentioned, we can see the effects of increasing contingency, especially in the electoral arena. But elections also clear room for contingency in other respects. Elections mean an opportunity to change government and, accordingly, also policy. However, in a cartel situation, changing policy is not in principle a primary aim, but it is most important to stay among those who have governmental power. Therefore, a cartel is usually based on status quo, which means that power relations inside a cartel result from previous power struggles. The main interest of the participants in a cartel is maintaining the status quo. The participants are not, on the first hand, interested in chances challenging the power relations between cartel parties. Accordingly, one can argue that politics in a cartelparty model easily takes on the struggle over power - the seats in government in particular.

This is exactly what has happened in Finland. Only the idea of a cartel-party model can 'explain' the exceptional party combination in the Finnish government - the "Rainbow Government" - which started in 1995 and is still continuing its work after the 1999 parliamentary election. The "Rainbow Government" consists of the Social Democratic Party, the National Coalition Party (the Conservatives), the Left-Wing Alliance (former Left-Socialists and Communists), the Swedish People's Party, and the Green League.

Politics understood as the art of winning elections temporalises politics in the sense that parliamentary politics can be separated from longstanding ideological goals. This can, however, have paradoxical results. On the one hand, this makes it possible to concentrate on short-term political objectives and make concrete promises to voters. On the other hand, abandoning great ideological narratives has left room for some very abstract apolitical slogans, such as "everyone 
has a right to happiness"7; however, these contrasts both have their usefulness. Abstract apolitical slogans are used in election campaigns. But when the question is of writing a programme for government cooperation for the next four years, both abstract ideological and apolitical slogans are put aside as useless, and usually only more concrete objectives and promises are written down.

Because of their unideological and apolitical stance, and in order to contest competition, cartel parties seem to be ready to give away their strong position with respect to voters. This can be seen in the politicians' readiness to follow voters' opinions and, accordingly, in the importance of opinion surveys for politicians and parties. Cartel parties do not seem to be willing to take the risk of trying to change voters' opinions, but seem to be 'flattering' the existing opinions. This may mean a tendency to avoid issues of conflict or writing down only positive aims when drafting the party programmes.

\section{Means of Politicisation or Means of Strengthening the Cartel-Party Model}

The increasing political contingency also poses new challenges to the concept of a party programme. This can be seen in the Finnish case. In fact, we can see two current contradictory tendencies. In order to avoid risks, and since nobody can predict the future in turbulent circumstances, the big parties have 'invented' the idea of a cartel to minimise 'common' risks. On the other hand, increasing contingency puts the conceptions of a party programme in motion and, accordingly, provides new opportunities for political actors. There is no longer merely one 'question' that everybody should try to answer, but many 'questions' and thus many 'answers'.

Aarnio (1998) has proved that by the end of the 1960s and the beginning of the 1970s, the programmatic process was characterised by ideological debates in nonsocialist parties and by dispute about ideological differences in socialist parties. As a consequence, the writing of a party programme turned from a monologue to a dialogue. Younger party members especially wanted to revise existing ideological debate. In many parties the question of the basis 
of support culminated in disputes between the young and the older 'conservative' generations in writing manifestos. In nonsocialist parties there were persons who realised that it was not possible to reach new supporters without breaking the harmony and consensus in the forum of manifestos. There were more debates than earlier, e.g., in newspapers, party conferences, and local meetings. In this period, taking initiative became habitual, inspiring new action and ideas. This increased the political character of the concept of a manifesto.

In the 1980s the churning out of special programmes settled and it became important to attain an active participation in the revision process. During the 1980s, there was a move towards a more innovative and open programme process. Party members were now encouraged to participate in the process and also the models and arenas of the process became diversified. Now party executives, instead of the rank-and-file members like in the 1960s and 1970s, emphasised the organisational democracy of parties during the programme process. This occurred simultaneously with decreasing party memberships. The milieu of parties had significantly changed. The range of questions experienced as political has been increased and the relation between the different questions has become more complex. This shift has created more opportunities for the politicisation of questions and institutionalised interpretations. However, institutionalised cartel parties have usually been unable or reluctant to utilise new chances for politicisation; rather they include in their agenda as far as it is possible - new questions, themes and issues which are already manifested by their challengers and new social movements in particular. The Greens especially have successfully introduced these kind of questions.

In the 1980s, there can also be seen a shift in the conceptions of a party programme from a completed paper to an interactive process. The rhetorical dimension appears when an academic-elitist process becomes replaced with one that is more communicative. Participation, or at least a sense of participation, is integral to the interactive process in that it facilitates the familiarisation with ideas presented in the process of speaking and writing a programme, and above all with different ways of thinking. The integrative rhetoric often used by key participants of the process aims at increasing the feeling of 
integrity and the continuity of an organisation, while the provocative rhetoric aims at rousing conversation and politicising questions.

It seems also evident that parties have become more dependent on 'external conversation'. It has become common for parties to utilise nonparty experts in the process of revising manifestos. They do not draw up manifestos, but stimulate debates on principles and alternative policies. Different parties listen to the same experts. This can be interpreted as an indication of the opening up of parties to outside influences and, thus, as a sign of parties losing their individual power and independent status. Their degree of institutionalisation is becoming weaker. On the other hand, the same features can also be seen indicating the transformation into cartel parties.

In the 1990s, taking part in speaking and writing party programmes also has other new 'functions'. It seems that even the writers of manifestos have to reflect on the future relevance of many topical themes and issues. They can not just give 'answers' satisfying the current situation. They must choose between various topical issues, questions and interpretations. In keeping up with the increasing number of political questions, the process of revising manifestos is an essential arena of practising and maintaining the participants' own political thinking. Everyday party life does not usually leave room for this kind of practice.

At the moment, many of those who profoundly participate in the process of writing party programmes are interested in continuous programmatic discussions, because the objectives of politics have changed and are in constant motion. The rhetorical aspects of manifestos have become crucial. Finally, the search for the legitimisation of any future action plays an important role in discussions between party members and leaders. These discussions are important because it is believed that they produce a wider range of commitments than appears in the accepted paper. The rhetorical aspects of manifestos also stress the necessity of preparing party members for the implementation of future decisions. The programme discussion also includes an explanation to party members and other audiences why it is no longer possible to simply introduce and begin to attain unambiguous targets. All things considered, discussions during the process of revising manifestos are related to the weakening ability of parties to control and to direct 'social discussions'. To put it briefly, par- 
ties have to listen to other political actors more sensitively than before.

\section{Conclusions}

The present system of organising political representation via political parties is a hybrid system in many ways. It has elements from all the three main traditions of political representation: 'the people as sovereign', 'parliament as sovereign' and the 'manifesto democracy'. This has resulted in conflicting conceptions of party programmes.

On the one hand, the established parties stress that their decisions should be derived from their programmes, confirmed together with the party organisation and in accordance with the "manifesto democracy'. However, the role of a party organisation often appears to be only ritual when party leaders are seeking a more stable status for themselves by repeating general issues which do not actually rouse conversation. Furthermore, Aarnio's analysis (1998) revealed that there still are plenty of persons - among rank-and-file members and party supporters in particular - who are looking for clear 'answers', and who would like to base their vote on the plans of rivalling parties. On the other hand, it is no longer possible to present detailed plans in programmes because of the increasing political contingency. This directs attention to a political actor and his/her capability to make decisions and to evaluate political situations independently according to the circumstances.

The status of political parties has changed dramatically in Finland since the late 1960s and early 1970s. At that time one could speak about 'party power'. Today parties and politicians have to compete for, or even struggle over, people's attention. This not only creates new demands on party politics and the conceptions of a party programme, but also - taking into account how conceptions of a party programme are in a state of flux - provides new chances for utilising party programmes as a means of politicisation. It seems evident that using a party programme as a means of politicisation presupposes taking distance from the models of mass-party, catch-all party and cartel party, and the conceptions of the party programme typical to each. 
Perhaps party programmes will increasingly initiate new debates. This was the way some Finnish programme writers of the 1990s described their conceptions of a party programme (for more of 'compete for symbolic power', see Aarnio 1998, 220-224). It was also interesting to see that those who emphasised the role of a party programme as an initiator of social and political debate also stressed the importance of the rhetoric of provocation more than the rhetoric of integration. The aim of a rhetoric of provocation is in utilising the increasing political contingency, and its starting point stems from the belief that nothing is certain. There are always chances for acting in another way. Thinking about the different political roles of a party, these new politicisers - i.e., 'political poets' - are more often than not accustomed socio-political debaters who usually come from outside the party bureaucracy. Party decision makers, bureaucrats, rankand-file members and party supporters still adhere more to the traditional mass-party model and the conception of a party programme typical to it. Top party leaders seem to be an exception in this respect. In Finnish politics there are clear signs, at the end of the 1990s, that party leaders are not very interested in 'ideological' party programmes, but seem to be more interested in and ready to emphasise more topical political issues. This again means, in the short run, increasing leader-centered party politics.

When we come to the 1990s it seems evident that the main Finnish political parties are wavering between two challenges. The main temptation appears to be the 'fruits' which the cartel situation seems to offer to its participants. The stability of the whole political system and political order is one of the most desired goals. The other challenge seems to be more risky - at least for cartel parties. The question here is taking full advantage of the increasing contingency in the electoral arena in particular.

Challenges posed by dealignment processes are also known for the main parties. They are trying to answer the challenge by developing and taking care of the cartel. Their more or less spontaneous answer has - in Finland, as elsewhere - been a contested competition in the electoral arena. Competition cannot totally be avoided, however, the cartel parties are willing to restrict the competition by trying to depoliticise the electoral struggle. This means avoiding - if possible - seriously conflicting issues in party programmes and in 
election competition. This is all the more important because big issues nowadays often divide parties from within. However, the writing process of a manifesto forms a profitable forum in which factions of a party can express their ideas and views. This debate does not usually appear as such in the programme, but it can serve as a medium in decreasing pressures inside a party.

Instead of trying consciously to politicise elections, cartel parties are competing with general and positive, but at the same time, vague themes which are often even common issues among the main parties. We can say 'common' in the sense that all main parties in the cartel are willing to discuss the same topic. This has resulted in video ads in elections, which today seem to have the role of an election programme, that increasingly resemble commercial advertisements, utilising more connotations and symbolism than traditional ideological narratives.

This inconvertible trend of general themes can easily be perceived when analysing the election manifestos for the 1999 parliamentary election. A party expressed a nonnegotiable goal extremely seldom. For example, the Greens would not participate in a government that engaged in the building of a fifth nuclear power plant.

Taking full advantage of increasing contingency might mean risking the whole cartel, or at least one's participation in the cartel. It is risky especially if a cartel party turns out to be unsuccessful in mobilising new voters to such a degree that it would impossible to ever think about a landslide victory. A big victory would, in principle, make it possible for a party either to enlarge its ability to politically manoeuvre within the cartel, or even to dissolve the cartel. So, the price of taking the risk and trying to fully utilise the increasing contingency and increased possibilities for political action can become high. Getting out of the cartel may mean being removed from the governing coalition and thereby losing the chances to deliver state funding to interest organizations and groups close to the party ${ }^{8}$. In 'normal circumstances', this is exactly the way cartel parties make themselves necessary and legitimate for party members, followers, and interest groups, by mediating between the state and civil society, i.e., how the cartel parties play their representative role.

Party programmes have at least three main functions or roles in the cartel model of today. For the cartel parties, the programme must 
have at least the following functions: The party programme should show in a convincing way that the party is up-to-date - that they understand what is going on in the world, Europe and in the country. Knowing the Zeitgeist is not, however, enough. The party and its programme also have to be able to show that the party understands what Zeitgeist means for the country, its citizens and in particular for party sympathisers - that the party is interested in its constituents. In order to be successful, the party must show 'knowing', 'knowhow', and empathetic understanding in the sense of 'I feel your pain'. All this is intended to help take the initiative in political discussion without, however, breaking up the cartel. Thirdly, it is significant to keep in mind that the drafting of a manifesto is an arena where the party's principles are chosen and legitimated. This means that, at the same time, the choices from a wide range of policies are made. The writing process provides an opportunity to discuss the possibilities and the bounds of action. This is particularly important when there are fractions within a party. It is important to prepare these fractions for future decision making.

Party programmes can have a very different role for parties outside the cartel. A programme can be a necessary tool in the endeavour of breaking up, or at least shaking up the cartel. Katz and Mair say this in the following way: "New parties seeking to break into the system may, of course, campaign for support on the basis of a wide variety of ideological appeals" (Katz and Mair, 24). This is, of course, possible for those main parties who wish to take the risk of challenging the cartel. Inside the cartel parties, the disintegration of one dominating conception of a party programme gives new room to those individuals and groups who are willing to use a programme process for politicising the struggle within a party.

\section{Notes}

${ }^{1}$ The empirical analysis of the changing conceptions of party programmes in Finland from the early 1950s to the 1990s is based on Eeva Aarnio's dissertation (Aarnio 1998). Her research material consisted of newspaper articles, materials from party congresses, archival records and interviews of both rank-and-file members and the key participants in party 
programme revision processes. The primary parties of the analysis are the Agrarian/Centre Party/Finnish Centre (Maalaisliitto/Keskustapuolue/ Suomen Keskusta r.p.) and the National Coalition Party (Kansallinen Kokoomus r.p.). Six other parties were also taken into consideration as secondary parties: the Finnish Christian Union, the Finnish Rural Party, the Left Wing Alliance, the Liberal People's Party, the Finnish Social Democratic Party and the Young Finns.

${ }^{2}$ See, for instance, Katz and Mair (1995), table 1, p. 18. Katz's and Mair's article is otherwise important, and we follow their model of the stages of party development.

${ }^{3}$ Following this idea we use, in the article, such phrases as a "programme forum' and a 'programme process'. Our intention in using these phrases is to emphasise that, in order to understand different conceptions of party programmes, we must take into account the whole process of a party programme starting from the need to reform an old programme and ending up with the use of a new programme for political action.

${ }^{4}$ Proportional representation, according to the d'Hondt allocation method, is used in Finland, and therefore election agreements are essential for smaller groups and parties.

${ }^{5}$ In Finland a party programme is given a priority in the hierarchy of programmes. Other manifestos, such as special and election programmes, are seen to derive from a party programme which is always confirmed by a party congress or another very authoritative body of a party. Wider party programmes and election programmes with short slogans and some essential themes have usually coexisted. Special programmes intended for special policy sectors, however, became common and popular only in the 1960s and 1970s.

${ }^{6}$ Note the new challenges to the so-called Scandinavian model, i.e., countries characterized as being exceptionally stable politically (Lane, Martikainen, Svensson, Vogt and Valen 1993). According to the authors, Scandinavian exceptionalism is now becoming history. "The major signs of instability showing up in Western Europe during the 1970s have finally reached highly stable Scandinavia. Volatility is up, the party system is changing and the welfare state has been reconsidered. The standard idioms about Nordic politics are no longer valid" (ibid., 196).

${ }^{7}$ The slogan of the Finnish Centre in the 1999 parliamentary election.

8 "In particular, there is the danger that a party that is excluded from government will also be excluded from access to resources" (Katz and Mair 1995, 16). 


\section{References}

Aarnio, Eeva (1998): Päämäärät liikkeessä. Puolueohjelmien kirjoittamisen muuttuvat merkitykset Suomessa 1950-luvulta 1990-luvulle. (English Summary). SoPhi 30. University of Jyväskylä.

Aldrich, John H. (1999): Political Parties in a Critical Era. American Politics Quarterly, Vol. 27 No. 1, pp. 9-32.

Birch, Anthony H. (1993): The Concepts and Theories of Modern Democracy. London: Routledge.

Blåfield, Antti \& Vuoristo, Pekka (1981): Kuka käyttää ja kenen valtaa. Puoluetoimisto toimii ja vaikuttaa. Suomen Kuvalehti 4.12.1981, pp. 1214.

Bryce, James (1886/1889): The American Commonwealth I-II. London: Macmillan.

Katz, Richard S. and Mair, Peter (1995): Changing Models of Party Organization and Party Democracy: The Emergence of the Cartel Party. Party Politics Volume 1, Number 1, pp. 5-28.

Kirchheimer, Otto (1996): The Transformation of West European Party Systems. In Joseph LaPalombara and Myron Weiner (eds.), Political Parties and Political Development. Princeton, NJ: Princeton University Press, pp. 177-200.

Lane Jan-Erik, Martikainen Tuomo, Svenssion Palle, Vogt Gunnar and Valen Henry (1993): Scandinavian Exceptionalism Reconsidered. Journal of Theoretical Politics 5 (2): 195-230.

Nousiainen, Jaakko (1959): Puolueet puntarissa. Helsinki: Kirjayhtymä 1959.

Palonen, Kari (1997): Vaalit, demokratisointi ja temporalisointi. James Bryce and Max Weber politiikan kontingenssista. Tiede E Edistys 1/1997, pp. 32-47.

Panebianco, Angelo (1988): Political parties: organization and power. Worcester: Cambridge University Press.

Pekonen, Kyösti (1984): Moderni politiikka ja vaalimainokset. Politiikka 2/1984, pp. 190-199.

Pekonen, Kyösti (1986): Imagon merkitys modernissa parlamentaarisessa politiikassa. In Jaakko Nousiainen \& Matti Wiberg (toim.), Kansalaiset ja politiikka 1980-luvun Suomessa. Turun yliopiston julkaisuja. Sarja C osa 57/1986, pp. 36-60.

Pekonen, Kyösti (1995): Finnish voters and the personification of politics. In Sami Borg \& Risto Sänkiaho (eds.): The Finnish Voter. Books from The Finnish Political Science Association. Tampere, pp. 187-207. 
Pekonen, Kyösti (1997): Kansa ja puolueet nyt: puolueiden toimintaympäristön muutos. In Sami Borg (toim.): Puolueet 1990-luvulla. Näkökulmia suomalaiseen puoluetoimintaan. Turun yliopisto, Valtio-opillisia tutkimuksia n:o 53, pp. 7-34.

Pesonen, Pertti (1995): The Evolution of Finland's Party Division and Social Structure. In Sami Borg \& Risto Sänkiaho (eds.), The Finnish Voter. Books from The Finnish Political Science Association. Tampere, pp. 9-22.

Skinner, Quentin (1974a): The Principles and Practice of Opposition: The Case of Bolingbroke versus Walpole. In Neil McKendrick (ed.), Historical Perspectives. London: Europa Publications, pp. 93-128.

Skinner, Quentin (1974b): Some Problems in the Analysis of Political Thought and Action, Political Theory, Vol. 2, pp. 277-301. 